\title{
The stereochemistry of addition of allyl sulfone carbanions to aldehydes. Formation of dihydrofurans ${ }^{1}$
}

\author{
Alfred Hassner,* Avital Laxer, and Eugene Ghera \\ Department of Chemistry, Bar-Ilan University, Ramat-Gan 52900, Israel \\ E-mail: hassna@mail.biu.ac.il
}

This paper is dedicated in friendship and with best wishes to Prof. Albert Padwa on the occasion of his $65^{\text {th }}$ birthday

(received 17 Jun 02; accepted 10 Oct 02; published on the web 18 Oct 02)

\begin{abstract}
The reaction of the mono-anion of the bromoallyl sulfone 1 with aldehydes 2 was examined with the aim of obtaining selectively substituted tetrahydrofurans. At $-100^{\circ} \mathrm{C}$ syn- and anti- open chain adducts $\mathbf{3}$ and $\mathbf{4}$ were isolated together with a low yield of 4-methylene-2,3-disubstituted tetrahydrofuran 5. In the presence of HMPA or at higher temperature the reaction led to formation of 2,5-dihydrofurans $\mathbf{6}$. The stereochemical results are consistent with initial addition of 1 to the aldehyde involving Li ion chelation.
\end{abstract}

Keywords: Dihydrofurans, Michael additions, allyl sulfones, Li chelation

\section{Introduction}

Recently we have shown ${ }^{2,3}$ that 2-(bromomethyl)-3-phenylsulfonyl-1-propene 1 reacts with one molar equivalent of LDA to generate a lithiated $\alpha$-allylsulfone carbanion that is stable at low temperature and undergoes regioselective and stereoselective additions via the $\alpha$-carbon to Michael acceptors such as unsaturated esters, ketones, sulfones and nitro compounds, followed by cyclization to methylene-cyclopentenes. For instance, in the case of unsaturated esters, the primary Michael adduct was not even isolable at $-78^{\circ} \mathrm{C}$ and the incipient carbanion immediately underwent intramolecular reaction with the allylic bromide to afford stereoselectively substituted methylenecyclopentane derivatives (eq. 1). ${ }^{2}$ The high stereoselectivity in the product can be rationalized on the basis of Li-ion chelation by the sulfone and the ester function during addition.

The addition of lithiated $\mathbf{1}$ to the $\mathrm{C}=\mathrm{N}$ of sulfinimines proceeded less stereoselectively and led with double bond rearrangement to 2 -arylpyrrolines. ${ }^{3 \mathrm{c}}$ 

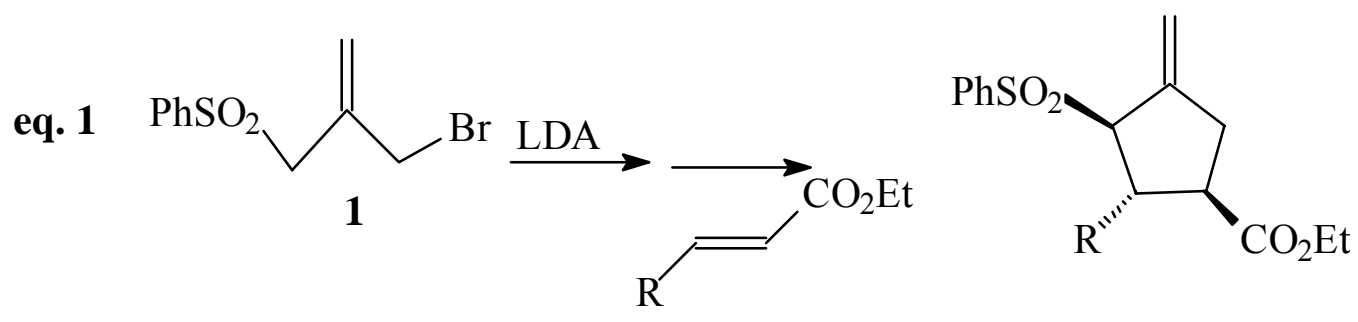

In view of general interest in formation of stereoselectively substituted tetrahydrofurans, such as the naturally occurring polyether antibiotics, ${ }^{4}$ we investigated the reaction of 1 with aldehydes as a potential entry into substituted tetrahydrofurans. We report here our findings, using the mono-lithio derivative of the bromoallyl sulfone $\mathbf{1}$ and of the hydroxyallylsulfone $\mathbf{8}$ in reactions with aldehydes 2 .

\section{Results and Discussion}

The bromoallylsulfone 1 was deprotonated using 1.1 equiv. of LDA in THF at $-100^{\circ} \mathrm{C}$. The monolithio derivative thus generated was treated with $p$-nitrobenzaldehyde $2 \mathbf{d}$ at the same temperature and quenched after 30 min with HOAc to give a mixture of two open chain syn- and anti- isomers, ${ }^{5} \mathbf{3}$ and $\mathbf{4}$, as well as the trans- 2,3-disubstituted-4-methylenetetrahydrofuran 5 (see eq. 2 and Table 1, entry 2).

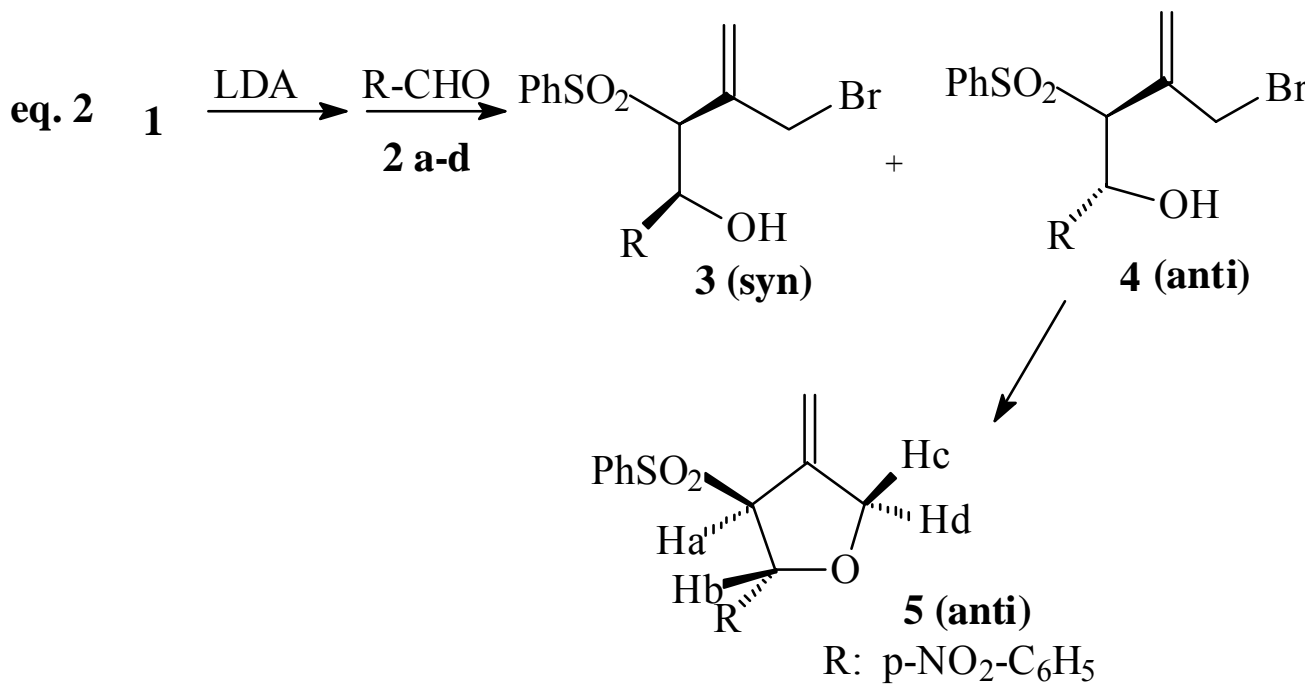

The syn- and anti- isomers $\mathbf{3}$ and $\mathbf{4}$ were separated by flash-column chromatography and their structures in the preferred conformation were assigned as $\mathbf{3 A}$ and $\mathbf{4 A}$, respectively, on the basis of NMR data. Similarly, the structure assignment of $\mathbf{5}$ is based on NMR (see discussion below). Addition of $\mathrm{LiBr}$ to the reaction mixture did not alter the results: however, addition of a solvating agent (TMEDA or especially HMPA) at $-100^{\circ} \mathrm{C}$ did change the ratio of products and led to 
isolation of the dihydrofuran $\mathbf{6 d}$, with the syn isomer 3 remaining unchanged (see Table 1). In two cases, ${ }^{7}$ a Michael adduct of the anion derived from product $\mathbf{5}$ to the aldehyde $2 \mathbf{d}$, was isolated in ca. $5 \%$ yield.
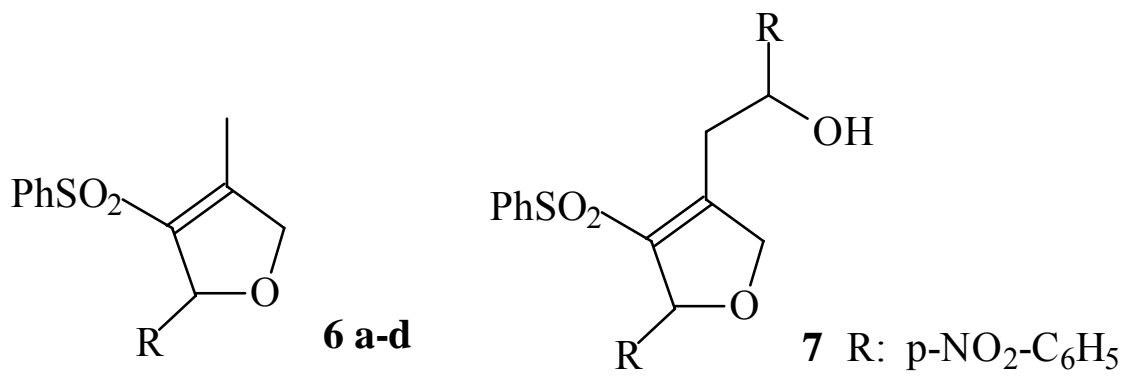

Reaction at higher temperature $\left(-40^{\circ} \mathrm{C}\right)$ for a longer period of time $(3 \mathrm{~h})$ in the absence of HMPA afforded the syn- isomer 3 together with rearranged dihydrofuran $\mathbf{6 d}$. When the monolithio derivative of $\mathbf{1}$ was treated with aldehyde 2d followed by HMPA in excess, and allowed to react at $-40^{\circ} \mathrm{C}$ for $3 \mathrm{~h}$, the only product isolated was the dihydrofuran $6 \mathbf{d}$ (see Table 1).

Table 1. Products 3-6 from reaction of $\mathbf{1}$ with 1.1 eq. of LDA followed by p-nitrobenzaldehyde, 2d

\begin{tabular}{cccccc}
\hline Entry & Conditions & 3, Yield (\%) & 4, Yield (\%) & 5, Yield (\%) & 6, Yield (\%) \\
\hline 1 & $0.5 \mathrm{~h},-100^{\circ} \mathrm{C}$ & 51 & 22 & 12 & - \\
2 & $0.5 \mathrm{~h},-100^{\circ} \mathrm{C}, \mathrm{LiBr}$ & 51 & 22 & 12 & - \\
$3^{\mathrm{a}}$ & $1 \mathrm{~h},-100^{\circ} \mathrm{C}, \mathrm{TMEDA}$ & 50 & 8 & 8 & 15 \\
$4^{\mathrm{a}}$ & $1 \mathrm{~h},-100^{\circ} \mathrm{C}, \mathrm{HMPA}$ & 50 & - & - & 27 \\
5 & $3 \mathrm{~h},-40^{\circ} \mathrm{C}$ & 50 & - & - & 25 \\
6 & $3 \mathrm{~h},-40^{\circ} \mathrm{C}, \mathrm{HMPA}$ & - & - & - & 48 \\
\hline
\end{tabular}

In this manner, several aliphatic and aromatic aldehydes $2 \mathbf{a}-\mathbf{d}$ were converted to the dihydrofurans 6a-d by means of the monolithio- derivative of $\mathbf{1}$ at $-40^{\circ} \mathrm{C}$ in the presence of HMPA, in good yields (see Table 2).

Table 2. Dihydrofurans 6 from reaction of $\mathbf{1}$ with LDA and aldehydes $\mathbf{2}$ (a-d) in the presence of HMPA at $-40^{\circ} \mathrm{C}$

\begin{tabular}{ccc}
\hline $\mathbf{2}$ & $\mathbf{R}$ & $\mathbf{6 ,}$ Yield (\%) \\
\hline $\mathrm{a}$ & $\mathrm{CH}_{3}\left(\mathrm{CH}_{2}\right)_{2}{ }^{-}$ & 63 \\
b & $\mathrm{CH}_{3}\left(\mathrm{CH}_{2}\right)_{4}{ }^{-}$ & 52 \\
c & $p$-Tolyl- & 85 \\
d & $p$-Nitrophenyl- & 48 \\
\hline
\end{tabular}


While this work was in progress, Najera et al. ${ }^{6}$ reported the formation of the dianion of the chloro analog of 1 using 2 equiv. of BuLi and DMPU and its reaction with alkyl halides and aldehydes (eq. 3). With alkyl halides, dialkylation took place. Allowing the reaction with aldehydes to proceed to room temperature, led to dihydrofuran analogs of $\mathbf{6}$, while the reaction with propanal and quenching at $-40^{\circ} \mathrm{C}$ gave a mixture of 6 and open-chain diastereomeric adducts. However, no separation of the latter, or their stereochemical elucidation, was reported.

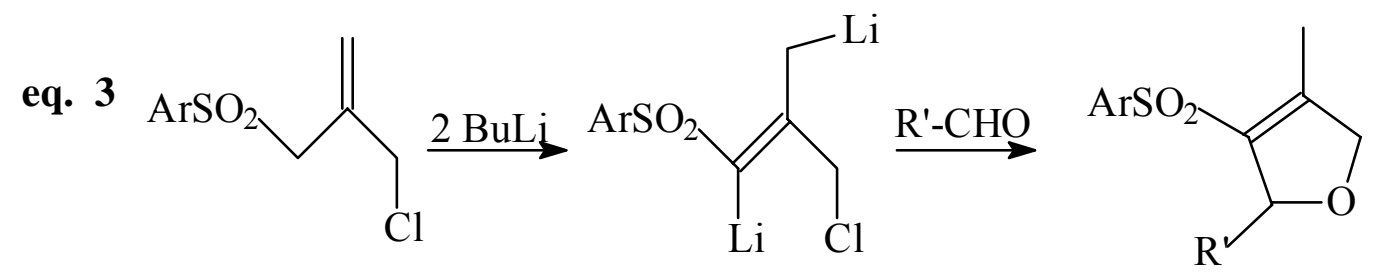

Our stereochemical results are best explained via the "cyclic model" in which the lithio allylsulfone carbanion reacts by an $\alpha$-carbon attack on the aldehyde leading to a chelated intermediate. As can be seen, the syn-chelated structure 3B (likely as a chair conformer of a 6membered ring with two equatorial groups) should be favored over syn- 3C or over anti- 4A ${ }^{7}$ because of gauche interactions; this explains why the syn product predominates.<smiles>[X]OC12CC(C(=C)CBr)C(C([R])C1[R])C2S(=O)(=O)c1ccccc1</smiles>

3A syn, $X=H$ 3B syn, $X=L i$<smiles>[R]C1C2C(C(=C)CBr)CC([R])(C2O[Al])C1S(=O)(=O)c1ccccc1</smiles>

3C syn
4A anti, $X=H$ 4B anti, $X=L i$<smiles>[X]OC1C(C(=C)CBr)C2([R])CC(S(=O)(=O)c3ccccc3)C1([2H])C2</smiles>

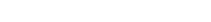<smiles>[Y1]C1C(O)C2C(S(=O)(=O)c3ccccc3)C([R])C1([R])C2(O)C(=C)CBr</smiles>

4C anti 
When chelation of the Li cation with sulfone- and alcohol- oxygens is disrupted, as in the presence of HMPA, rotation can occur to $\mathbf{3 C}$ and $\mathbf{4 B}$, respectively, ${ }^{7}$ conformers needed for subsequent cyclization. In this case, it is the anti- isomer in its anionic form (4B or $\mathbf{4 C}$ ) which is expected to ring-close to a tetrahydrofuran 5, while steric hindrance inherent in vicinally cisdisubstituted five-membered rings should raise the transition state energy for the cyclization of syn- 3C. Indeed, only cyclization of the anti- isomer to the trans- tetrahydrofuran $\mathbf{5}$ was observed at $-100^{\circ} \mathrm{C}$ (Table 1, entry 4). At higher temperature and in the presence of HMPA and base, ring closure of both diastereomers took place followed by isomerisation to the dihydrofuran $\mathbf{6}$, as well as side reactions. The above series of events is consistent with the products which we had observed in the reaction of $\mathbf{1}$ with $\omega$-nitrostyrene, in which the anti- adduct ring-closed more readily (to the trans- substituted cyclopentane) than did the syn- isomer. ${ }^{3 \mathrm{~b}}$

It was hoped that chelation to the hydroxyallylsulfone 8 might lead to higher stereoselectivity during the addition to the carbonyl group by complexation, as shown in $\mathbf{9}$. In fact, the hydroxyallylsulfone 8 had been shown to add regio- and stereoselectively to nitro-olefins. ${ }^{8}$ Hence, we also examined the condensation of the Li derivative of $\mathbf{8}$ with hexanal $\mathbf{2} \mathbf{b}$. In this case, however, two diastereomers 10 (syn-) and 11 (anti-) were formed in essentially equal amounts and addition of TMEDA did not change the results. Apparently, in this system chelation of the Li cation from the aldehyde to the sulfone or the hydroxy group are either not important, or more likely, equal.

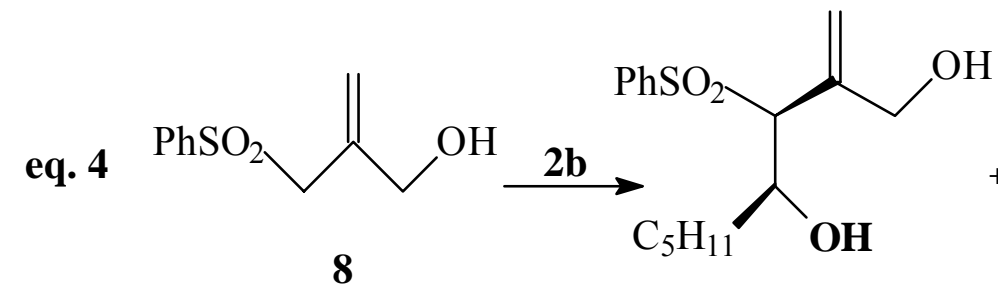

10 syn

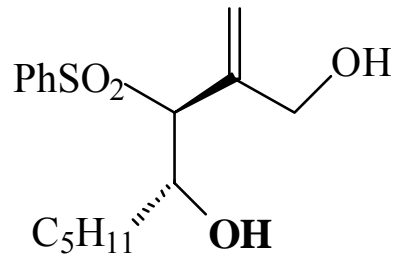

11 anti

\section{Structure assignment}

The configurational assignment of $\mathbf{3 A}$ as the syn- isomer is based on a value of $9 \mathrm{~Hz}$ for the coupling constant between $\mathrm{H}_{\mathrm{a}}$ and $\mathrm{H}_{\mathrm{b}}$ indicating an anti- relationship. In the second isomer 4A the corresponding coupling constant is $2.5 \mathrm{~Hz}$, consistent with a gauche orientation of $\mathrm{H}_{\mathrm{a}}$ and $\mathrm{H}_{\mathrm{b}}$. In both isomers the hydroxylic proton exhibits a doublet with coupling to $\mathrm{H}_{\mathrm{b}}$ of $2 \mathrm{~Hz}$. This phenomenon is known in cases where the exchange rate of the hydroxylic proton is very low and may be due to hydrogen bonding. The determination of configuration of the trans- substituted tetrahydrofuran 5 is also based on a $4 \mathrm{~Hz}$ coupling between $\mathrm{H}_{\mathrm{a}}$ and $\mathrm{H}_{\mathrm{b}}$. Although configurational assignment in 5-membered rings based on NMR should be made with caution in cyclopentanes that are rather flat, trans- vicinal hydrogens usually show a small coupling constant of $2-4 \mathrm{~Hz}$ (dihedral angle near $120^{\circ}$ ) while cis- vicinal hydrogens exhibit a larger coupling constant of 8-11 $\mathrm{Hz}$ (dihedral angle closer to $0^{\circ}$ ). In the case of 5 the assumption that the ring is rather flat is well 
founded since (a) there is an $\mathrm{sp}^{2}$ hybridized center in the ring, (b) the 5-membered ring contains an oxygen atom, (c) each of the vinylic protons shows three similar allylic couplings (with $\mathrm{H}_{\mathrm{a}}$, $\mathrm{H}_{\mathrm{c}}, \mathrm{H}_{\mathrm{d}}$ ). This is consistent with having $\mathrm{C}_{3}, \mathrm{C}_{4}, \mathrm{C}_{5}$ in nearly the same plane. More convincing is the NOE $(2 \%)$ observed in 5 between $\mathrm{H}_{\mathrm{a}}$ and the ortho- hydrogens of the cis- $p$-nitrophenyl ring, as well as between $\mathrm{H}_{\mathrm{a}}$ and $\mathrm{H}_{\mathrm{d}}$ and between $\mathrm{H}_{\mathrm{b}}$ and $\mathrm{H}_{\mathrm{c}}$.

In conclusion, the lithio allylsulfone carbanion derived from $\mathbf{1}$ added stereoselectively to aldehydes to produce preferentially the syn- adduct at low temperature $\left(-100^{\circ} \mathrm{C}\right)$. This is best explained by a chelated intermediate $\mathbf{3 B}$, while at higher temperature and in the presence of HMPA, ring-closure and finally isomerisation to the dihydrofuran $\mathbf{6}$ took place. There was no stereochemical preference in the addition of hydroxysulfone $\mathbf{8}$ to aldehyde $\mathbf{2 b}$.

\section{Experimental Section}

General anhydrous experimental techniques and analytical measurements were as previously described. ${ }^{8}$

\section{General procedure for the reaction of 1 with $p$-nitrobenzaldehyde (2d); Formation of 3-7}

To a stirred solution of LDA (prepared from $0.14 \mathrm{~mL}(1 \mathrm{mmol})$ of diisopropylamine and $0.64 \mathrm{~mL}$ of n-BuLi (0.92 mmol, $1.475 \mathrm{~N}$ in hexane) in $4 \mathrm{~mL}$ of THF) was added dropwise at $100^{\circ} \mathrm{C}$ a solution of $1(200 \mathrm{mg}, 0.72 \mathrm{mmol})$ in $1 \mathrm{~mL}$ of THF. After stirring for $10 \mathrm{~min}$ at the above temperature, $p$-nitrobenzaldehyde $(121 \mathrm{mg}, 0.08 \mathrm{mmol})$ in $1 \mathrm{~mL}$ of THF was added dropwise. After $15 \mathrm{~min}$, at $-100^{\circ} \mathrm{C}$, the reaction mixture was quenched with aqueous $(20 \%)$ $\mathrm{AcOH}$, poured into water, and extracted with $\mathrm{CH}_{2} \mathrm{Cl}_{2}$. The extracts were washed successively with saturated $\mathrm{NaHCO}_{3}$ solution and brine, dried $\left(\mathrm{MgSO}_{4}\right)$, and evaporated under reduced pressure. Chromatographic purification of the residue (ether/petroleum ether, 1:2) gave compounds 3-7, as viscous oils. Yields are reported in Table 1.

2-Bromomethyl-4-(p-nitrophenyl)-3-benzenesulfonyl-1-buten-4-ol (syn) (3). ${ }^{1} \mathrm{H}$ NMR $\delta 8.18$ $8.08(\mathrm{~m}, 2 \mathrm{H}), 7.94-7.85(\mathrm{~m}, 2 \mathrm{H}), 7.76-7.48(\mathrm{~m} \mathrm{5H}), 5.53-5.40(\mathrm{~m}, 3 \mathrm{H}), 4.60(\mathrm{~d}, \mathrm{~J}=2 \mathrm{~Hz}, 1 \mathrm{H})$, $4.13(\mathrm{dd}, \mathrm{J}=9,1 \mathrm{~Hz}, 1 \mathrm{H}), 3.46(\mathrm{dd}, \mathrm{J}=11,1 \mathrm{~Hz}, 1 \mathrm{H}), 3.21(\mathrm{dd}, \mathrm{J}=11,1 \mathrm{H}) .{ }^{13} \mathrm{C}$ NMR $\delta 147.9$ (s), 145.9 (s), 137.1 (s), 135.1 (s), 134.5 (d), 129.6 (d), 129.1 (d), 128.9 (d), 124.3 (t), 123.3 (d), 73.3 (d), 72.3 (d), 36.1 (t). M.S. $\left(\mathrm{CH}_{4} / \mathrm{CI}\right) \mathrm{m} / \mathrm{e}(\%)$ : 443, $445\left(\mathrm{MH}^{+}, 84,100\right), 363\left(\mathrm{MH}^{+}-\mathrm{HBr}\right.$, 11); HRMS: calcd. $\left(\mathrm{C}_{17} \mathrm{H}_{17} \mathrm{NO}_{5} \mathrm{SBr}, \mathrm{MH}^{+}\right)$427.9990, 426.0010, found 427.9410, 425.9447.

2-Bromomethyl-4-(p-nitrophenyl)-3-benzenesulfonyl-1-buten-4-ol (anti) (4). ${ }^{1} \mathrm{H} \mathrm{NMR} \delta$ 8.20-8.11 (m, 2H), 7.95-7.84 (m, 2H), 7.75-7.67 (m, 1H), 7.63-7.43 (m, 4H), 6.11 (s, 1H), 5.83 (BS, 1H), $5.67(\mathrm{~s}, 1 \mathrm{H}), 3.95(\mathrm{dd}, \mathrm{J}=2.5,1 \mathrm{~Hz}, 1 \mathrm{H}), 3.83(\mathrm{~d}, \mathrm{~J}=2 \mathrm{~Hz}, 1 \mathrm{H}), 3.49$ (dd, J = 11, $1 \mathrm{~Hz}$, 1H), 3.18 (dd, J = 11, 1Hz, 1H). ${ }^{13} \mathrm{C}$ NMR $\delta 147.6$ (s), 146.0 (s), 136.7 (s), 134.5 (d), 132.1 (s), 129.2 (d), 129.1 (t), 127.2 (d), 126.1 (d), 123.4 (d), 70.9 (d), 69.8 (d), 37.3 (t). M.S. (ammonia/CI) m/e (\%): 443, $\left.445\left(\mathrm{NH}_{3}+\mathrm{MH}\right)^{+}, 50,58\right), 363\left(\mathrm{NH}_{3}+\mathrm{MH}^{+}-\mathrm{HBr}, 100\right), 316$ $\left(\mathrm{NH}_{3}+\mathrm{MH}^{+}-\mathrm{HBr}-\mathrm{HNO}_{2}, 13\right)$. 
4-Methylene-trans-2-(p-nitrophenyl)-3-benzenesulfonyltetrahydrofuran (5). ${ }^{1} \mathrm{H} \quad \mathrm{NMR} \delta$ 8.23-8.14 (m, 2H), 7.98-7.90 (m, 2H), 7.77-7.69 (m, 1H), 7.66-7.56 (m, 2H), 7.51-7.43 (m, 2H), $5.72(\mathrm{~d}, \mathrm{~J}=4 \mathrm{~Hz}, 1 \mathrm{H}), 5.32(\mathrm{dt}, \mathrm{J}=13,1 \mathrm{~Hz}), 4.35(\mathrm{dq}, \mathrm{J}=13,2 \mathrm{~Hz}, 1 \mathrm{H})$ 4.09-4.02 (m, 1H). ${ }^{13} \mathrm{C}$ NMR $\delta 149.1$ (s), 147.6 (s), 139.4 (s), 136.5 (s), 134.4 (d), 129.7 (d), 129.2 (d), 126.5 (d), 123.8 (d), 114.3 (t), 80.0 (d), 72.3 (t). M.S. (iso-butane/CI) m/e (\%): $346\left(\mathrm{MH}^{+}, 21\right), 203$ $\left(\mathrm{M}^{+}-\mathrm{HSO}_{2} \mathrm{Ph}, 100\right)$.

2-(p-Nitrophenyl)-3-benzenesulfonyl-4-(1'-p-nitrophenyl-2'-ethyl-1'-ol)-2,5-dihydrofuran (7). ${ }^{1} \mathrm{H}$ NMR $\delta 8.32-8.24(\mathrm{~m}, 2 \mathrm{H}), 8.15-7.99(\mathrm{~m}, 2 \mathrm{H}), 7.72-7.63(\mathrm{~m}, 2 \mathrm{H}), 7.50-7.48(\mathrm{~m}, 2 \mathrm{H})$, 7.44-7.37 (m, 2H), 7.30-6.63 (m, 4H), $5.91(\mathrm{dd}, \mathrm{J}=5.7,3.7 \mathrm{~Hz}, 1 \mathrm{H}), 5.22(\mathrm{dt}, \mathrm{J}=7.4,5.5 \mathrm{~Hz}$, 1H), $5.00(\mathrm{dd}, \mathrm{J}=15.5,5.5 \mathrm{~Hz}, 1 \mathrm{H}), 4.89(\mathrm{dd}, \mathrm{J}=15.5,3 \mathrm{~Hz}, 1 \mathrm{H}), 3.24-3.14(\mathrm{~m}, 3 \mathrm{H}) .{ }^{13} \mathrm{C}$ NMR $\delta 152.0$ (s), 150.5 (s), 148.1 (s), 147.7 (s), 145.6 (s), 139.6 (s), 136.5 (s), 133.9 (d), 129.1 (d), 128.8 (d), 127.2 (d), 126.3 (d), 124.0 (d), 123.4 (d), 87.6 (d), 79.2 (t), 72.1 (d), 35.6 (t). M.S. (ammonia/CI) m/e (\%): $514\left(\mathrm{MNH}_{4}^{+}, 100\right), 449\left(\mathrm{M}^{+}-\mathrm{HNO}_{2}, 52\right), 419\left(\mathrm{MH}^{+}-\mathrm{Ph}, 46\right), 373$ $\left(\mathrm{MNH}_{4}{ }^{+}-\mathrm{SO}_{2} \mathrm{Ph}, 5\right)$.

General procedure for the reaction of aldehydes (2a-d) with 1-benzenesulfonyl-2methylene-3-bromopropane (1); preparation of compounds (6a-d)

To a stirred solution of LDA (prepared from $0.07 \mathrm{~mL}(0.5 \mathrm{mmol})$ of diisopropylamine and $0.32 \mathrm{~mL}$ of $\mathrm{n}-\mathrm{BuLi}(0.46 \mathrm{mmol}, 1.475 \mathrm{~N}$ in hexane) in $2 \mathrm{~mL}$ of THF) was added dropwise at $100^{\circ} \mathrm{C}$ a solution of $1(100 \mathrm{mg}, 0.36 \mathrm{mmol})$ in $0.5 \mathrm{~mL}$ of THF. After stirring for $10 \mathrm{~min}$ at the above temperature, the aldehyde 2 (a-d) $(0.4 \mathrm{mmol})$ in $0.5 \mathrm{~mL}$ of THF was added dropwise. After addition of the aldehyde, a mixture of HMPA $(0.5 \mathrm{~mL})$ and THF $(0.4 \mathrm{~mL})$ was added dropwise at $-100^{\circ} \mathrm{C}$. The mixture was stirred for an additional $3 \mathrm{~h}$ at $-40^{\circ} \mathrm{C}$ and then quenched with aqueous $\mathrm{AcOH}(20 \%)$, poured into water, and extracted with $\mathrm{CH}_{2} \mathrm{Cl}_{2}$. The extracts were washed successively with saturated $\mathrm{NaHCO}_{3}$ solution and brine, dried $\left(\mathrm{MgSO}_{4}\right)$, and evaporated under reduced pressure. Chromatographic purification of the residue (petroleum ether/ether, 2:1) gave the desired product $(\mathbf{6 a}-\mathbf{d})$.

4-Methyl-3-benzenesulfonyl-2-propyl-2,5-dihydrofuran (6a) was obtained from $\mathbf{1}$ and butyraldehyde (2a) as a viscous liquid (60 mg, $0.23 \mathrm{mmol}, 63 \%) .{ }^{1} \mathrm{H}$ NMR $\delta 7.94-7.83(\mathrm{~m}, 2 \mathrm{H})$, 7.70-7.51 (m, 3H), 4.99-4.85 (m, 1H), $4.67(\mathrm{dd}, \mathrm{J}=14,5 \mathrm{~Hz}, 1 \mathrm{H}), 4.54(\mathrm{dd}, \mathrm{J}=14,3 \mathrm{~Hz}, 1 \mathrm{H})$, 2.15 (s, 3H) 1.86-1.46 (m, 2H), 1.39-1.12 (m, 2H) $0.85(\mathrm{t}, \mathrm{J}=7 \mathrm{~Hz}, 3 \mathrm{H}) .{ }^{13} \mathrm{C}$ NMR $\delta 150.7(\mathrm{~s})$, $141.3(\mathrm{~s}), 133.9$ (s), 133.5 (d), 129.2 (d), 127.2 (d), 86.7 (d), 78.9 (t), 36.9 (t), 17.8 (t), 13.8 (q), 11.3 (q). M.S. (EI) m/e (\%): $267\left(\mathrm{MH}^{+}, 100\right), 223\left(\mathrm{MH}^{+}-\mathrm{C}_{3} \mathrm{H}_{8}, 99\right) 141\left(\mathrm{SO}_{2} \mathrm{Ph}^{+}, 37\right), 125$ $\left(\mathrm{SO}_{2} \mathrm{Ph}^{+}-\mathrm{O}, 57\right), 77\left(\mathrm{Ph}^{+}, 78\right)$; HRMS calcd. $\left(\mathrm{C}_{14} \mathrm{H}_{19} \mathrm{O}_{3} \mathrm{~S}, \mathrm{MH}+\right)$ 267.1054, found 267.0881 .

4-Methyl-2-pentyl-3-benzenesulfonyl-2,5-dihydrofuran (6b) was obtained from 1 and hexanal (2b) as a viscous liquid (55 mg, $0.19 \mathrm{mg}, 52 \%) .{ }^{1} \mathrm{H}$ NMR $\delta 7.94-7.83(\mathrm{~m}, 2 \mathrm{H}), 7.69-7.50$ (m, $3 \mathrm{H}) 5.00-4.87(\mathrm{~m} .1 \mathrm{H}), 4.67(\mathrm{dd}, \mathrm{J}=16,5 \mathrm{~Hz}, 1 \mathrm{H}), 4.55(\mathrm{dd}, \mathrm{J}=16,4 \mathrm{~Hz}, 1 \mathrm{H}), 2.15(\mathrm{~s}, 3 \mathrm{H})$ 1.92-1.04 (m, 8H), $0.84(\mathrm{t}, \mathrm{J}=6 \mathrm{~Hz}, 3 \mathrm{H}) .{ }^{13} \mathrm{C}$ NMR $\delta 150.7$ (s), 141.3 (s), 133.7 (s), $133.4(\mathrm{~d})$, $129.2(\mathrm{~d}), 127.1(\mathrm{~d}), 86.8(\mathrm{~d}), 78.8(\mathrm{t}), 34.7(\mathrm{t}), 31.5(\mathrm{t}), 24.1(\mathrm{t}), 22.5(\mathrm{t}), 13.9(\mathrm{q}), 11.2(\mathrm{q})$. M.S. 
(EI) m/e (\%): $295\left(\mathrm{MH}^{+}, 97\right), 223\left(\mathrm{MH}^{+}-\mathrm{C}_{5} \mathrm{H}_{12}, 100\right) 141\left(\mathrm{SO}_{2} \mathrm{Ph}^{+}, 28\right) 125\left(\mathrm{SO}_{2} \mathrm{Ph}^{+}-\mathrm{O}, 23\right), 77$ $\left(\mathrm{Ph}^{+}, 76\right)$; HRMS calcd. $\left(\mathrm{C}_{16} \mathrm{H}_{23} \mathrm{O}_{3} \mathrm{~S}, \mathrm{MH}^{+}\right)$295.1367, found 295.1274.

4-Methyl-3-benzenesulfonyl-2-(p-tolyl)-2,5-dihydrofuran (6c) was obtained from 1 and $p$ tolyl-benzaldehyde (2c) as a white solid $\left(96.4 \mathrm{mg}, 0.306 \mathrm{mmol}, 85 \%\right.$, m.p. $\left.123.7^{\circ} \mathrm{C}\right) .{ }^{1} \mathrm{H} \mathrm{NMR} \delta$ 7.51-7.39 (m, 1H), 7.32-7.17 (m, 4H), 6.99-6.89 (m, 4H), 5.93-5.87 (m, 1H), 4.88 (dd, J = 15, $5.5 \mathrm{~Hz}, 1 \mathrm{H}), 4.78(\mathrm{dd}, \mathrm{J}=15,3.5 \mathrm{~Hz}, 1 \mathrm{H}), 2.29(\mathrm{~s}, 6 \mathrm{H}) .{ }^{13} \mathrm{C}$ NMR $\delta 150.5(\mathrm{~s}), 141.0(\mathrm{~s}), 138.4$ (s), 136.0 (s), 135.7 (d), 128.9 (d), 128.6 (d), 127.9 (d), 127.3 (d), 89.0 (d), 79.7 (t), 21.2 (q), 11.4 (q). M.S. (iso-butane/CI) m/e (\%): $\left.332\left(\mathrm{MH}_{2} \mathrm{O}^{+}, 6\right) 315\left(\mathrm{MH}^{+}, 13\right) 297\left(\mathrm{MH}^{+}-\mathrm{H}_{2} \mathrm{O}\right), 8\right), 223$ $\left(\mathrm{M}^{+}-\mathrm{C}_{7} \mathrm{H}_{7}^{+}, 100\right), 173\left(\mathrm{M}^{+}-\mathrm{SO}_{2} \mathrm{Ph}^{+}, 2\right)$.

4-Methyl-3-benzenesulfonyl-2-(p-nitrophenyl)-2,5-dihydrofuran (6d) was obtained from 1 and $p$-nitrobenzaldehyde (2d) as a yellow solid (60 mg, $0.173 \mathrm{mmol}, 48 \%$, m.p. $\left.224.2{ }^{\circ} \mathrm{C}\right) .{ }^{1} \mathrm{H}$ NMR $\delta$ 8.02-7.94 (m, 2H), 7.51-7.19 (m, 7H), 6.05-5.97 (m, 1H), $4.96(\mathrm{dd}, \mathrm{J}=15,5 \mathrm{~Hz}, 1 \mathrm{H})$, $4.85(\mathrm{dd}, \mathrm{J}=15,4 \mathrm{~Hz}, 1 \mathrm{H}), 2.33(\mathrm{~s}, 3 \mathrm{H}) .{ }^{13} \mathrm{C} \mathrm{NMR} \delta 151.8$ (s), 148.0 (s), 146.0 (s), 140.7 (s), 134.4 (s), 133.3 (d), 128.8 (d), 127.0 (d), 123.3 (d), 87.9 (d), 80.1 (t), 11.4 (q). M.S. (isobutane/CI) m/e (\%): $\left.346\left(\mathrm{MH}^{+}, 100\right), 323\left(\mathrm{MH}^{+}-\mathrm{H}_{2} \mathrm{O}\right), 58\right), 223\left(\mathrm{M}^{+}-\mathrm{NO}_{2} \mathrm{Ph}^{+}, 47\right), 204\left(\mathrm{M}^{+}-\right.$ $\left.\mathrm{SO}_{2} \mathrm{Ph}^{+}, 62\right), 158\left(\mathrm{M}^{+}-\mathrm{SO}_{2} \mathrm{Ph}^{+}-\mathrm{NO}_{2} \mathrm{Ph}^{+}, 9\right)$; HRMS calcd $\left(\mathrm{C}_{17} \mathrm{H}_{16} \mathrm{NO}_{5} \mathrm{~S}, \mathrm{MH}^{+}\right)$346.0749, found 346.0738 .

General procedure for the reaction of hexanal (2b) with 1-benezenesulfonyl-2-methylene-3hydroxypropane (8); preparation of compounds (10-11)

To a stirred solution of LDA (prepared from $0.17 \mathrm{~mL}(1.2 \mathrm{mmol})$ of diisopropylamine and $0.94 \mathrm{~mL}$ of $\mathrm{n}-\mathrm{BuLi}(1.2 \mathrm{mmol}, 1.475 \mathrm{~N}$ in hexane) in $4 \mathrm{~mL}$ of THF) was added dropwise at $100^{\circ} \mathrm{C}$ a solution of $8(100 \mathrm{mg}, 0.48 \mathrm{mmol})$ in $1 \mathrm{~mL}$ of THF. After stirring for $10 \mathrm{~min}$ at the above temperature, the hexanal $2 \mathbf{b}(58 \mathrm{mg}, 0.58 \mathrm{mmol})$ in $0.5 \mathrm{~mL}$ of THF was added dropwise. The mixture was stirred for an additional $1 \mathrm{~h}$ at $-100^{\circ} \mathrm{C}$ and then quenched and extracted as described for 6(a-d). Chromatographic purification of the residue (petroleum ether / ethyl acetate, 1:1) gave products 10 and $11(66 \mathrm{mg}, 0.21 \mathrm{mmol}, 44 \%)(10: 11=1.28: 1)$ as a viscous oil (inseparable mixture).

2-Methylene-3-(benzenesulfonyl)nonane-1,4-diol (10, syn) a and (11, anti) b. ${ }^{1} \mathrm{H}$ NMR $\delta$ 7.91-7.83 (m, 2Ha, 2Hb), 7.72-7.48 (m, 3Ha, 3Hb), $5.47(\mathrm{~s}, 1 \mathrm{Hb}), 5.40(\mathrm{~s}, 1 \mathrm{Ha}), 5.36(\mathrm{~s}, 1 \mathrm{Hb})$, 5.03 (s, 1Ha), 4.93-4.46 (m, 3Ha, 3Hb), 3.85 (d, J = 9 Hz, 1Hb), 3.75 (d, J = 2 Hz, 1Ha), 3.68$3.59(\mathrm{~m}, 1 \mathrm{Ha}, 1 \mathrm{Hb}), 2.91(\mathrm{t}, \mathrm{J}=6 \mathrm{~Hz}, 1 \mathrm{Hb}), 2.35(\mathrm{t}, \mathrm{J}=6 \mathrm{~Hz}, 1 \mathrm{Ha}), 1.66-1.13(\mathrm{~m}, 8 \mathrm{Ha}, 8 \mathrm{Hb})$, 0.94-0.79 (m, 3Ha, 3Hb). ${ }^{13} \mathrm{C} \operatorname{NMR} \delta 139.5$ (s, a), 137.7 (s, b), 137.5 (s, b), 137.1 (s, a), 134.0 (d, b), 133.9 (d, a), 129.1 (d, b), 129.0 (d, a), 128.9 (d, a), 128.7 (d, b), 123.9 (t, b), 119.5 (t, a), 73.2 (d, a), $72.4(\mathrm{~d}, \mathrm{~b}), 70.3(\mathrm{~d}, \mathrm{a}), 68.5(\mathrm{~d}, \mathrm{~b}), 65.6(\mathrm{t}, \mathrm{a}), 65.3(\mathrm{t}, \mathrm{b}), 34.5(\mathrm{t}, \mathrm{b}), 34.3(\mathrm{t}, \mathrm{a}), 31.5$ (t, a), 31.4 (t, b), $25.3(\mathrm{t}, \mathrm{b}), 24.7(\mathrm{t}, \mathrm{a}), 22.5$ (t, a), 22.4 (t, b), 13.9 (q, a, b). M.S. (CH4/CI) m/e (\%): $313\left(\mathrm{MH}^{+}, 32\right), 295\left(\mathrm{MH}^{+}-\mathrm{H}_{2} \mathrm{O}, 100\right), 277\left(\mathrm{MH}^{+}-2 \mathrm{H}_{2} \mathrm{O}, 8\right), 195\left(\mathrm{M}^{+}-\mathrm{H}_{2} \mathrm{O} \mathrm{C}_{6} \mathrm{H}_{12} \mathrm{O}, 10\right)$; HRMS: calcd. $\left(\mathrm{C}_{16} \mathrm{H}_{25} \mathrm{O}_{4} \mathrm{~S}, \mathrm{MH}^{+}\right) 313.1473$, found 313.1378 . 


\section{Acknowledgments}

Support of this research by a grant from the Marcus Center for Medicinal and Pharmaceutical Chemistry is gratefully acknowledged. We thank Dr. H.E. Gottlieb for valuable help with NMR structure elucidation.

\section{References and Notes}

1. Stereochemistry 94. For Part 93 see Kumareswaran, R.; Hassner, A. Tetrahedron Asymmetry 2001, 12, 3409.

2. (a) Ghera, E.; Yehezkel, T.; Hassner, A. Tetrahedron Lett. 1990, 31, 3653. (b) Idem. J. Org. Chem. 1996, 61, 4959.

3. (a) Ghera, E.; Yehezkel, T.; Hassner, A. J. Org. Chem. 1993, 58, 6716. (b) Hassner, A.; Ghera, E.; Yechezkel, T.; Kleiman, V.; Balasubramanian, T.; Ostercamp, D. Pure Appl. Chem. 2000, 72, 1671. (c) Balasubramanian, T.; Hassner, A. Tetrahedron Lett. 1996, 37, 5755.

4. For a review see Boivin, T.L.B. Tetrahedron 1987, 43, 3309.

5. Najera, C.; Sansano, J.M. Tetrahedron Lett. 1992, 33, 6543.

6. The syn- and anti-nomenclature, used here, is the one proposed by Oare, D.A., Heathcock, C.H. Topics in Stereochemistry; Eliel, E.L., Wilen, S.H., Eds; Wiley: New York, 1990, Vol. 19, pp 227, for Michael additions. In such Michael adducts the extended chain contains the two anion- stabilizing groups. In the case of 3 and 4 the $\mathrm{PhSO}_{2}$ and the $\mathrm{OH}$ are part of the extended chain and the R- and allyl bromide substituents can be syn- or anti- oriented.

7. We are ignoring conformations in which the $p$-nitrophenyl group $(\mathrm{R})$ is gauche to the two large groups ( $\mathrm{PhSO}_{2}$ and allyl bromide).

8. Ghera, E.; Yechezkel, T.; Hassner, A. J. Org. Chem. 1990, 55, 5977. 